\title{
Possible Scenarios of Russian Luxury Market Development under Economic Uncertainty and Turbulence
}

\author{
Irina Skorobogatykh ${ }^{1}$, Elvira Tarasenko ${ }^{1} \&$ Irina Shirochenskaya ${ }^{1}$ \\ ${ }^{1}$ Department of Marketing, Plekhanov Russian University of Economics, Moscow, Russian Federation \\ Correspondence: Skorobogatykh Irina Ivanovna, 19-119, Sumskoy proezd, Moscow, 117208, Russian Federation. \\ Tel: 7-903-740-8585. E-mail: skorobogatykh.II@rea.ru
}

Received: March 11, 2015 Accepted: March 30, 2015 Online Published: May 22, 2015

doi:10.5539/res.v7n9p131 URL: http://dx.doi.org/10.5539/res.v7n9p131

\begin{abstract}
Unstable political and economic situation in Russia and in the whole world affect all the product markets. In 2014 in Russia, the downturn of purchasing activities of customers was registered and as a result the decrease of the sales on the auto moto market, the retail market as a whole were registered as well. The market of luxury and premium products and services is also affected by economic uncertainty and turbulence. Experts had forecasted the changes in the consumer behavior and turn of the consumers to the less expensive and prestige products and services. This article is describing the typology of consumer behavior in Russia during economic unstable external marketing environment and turbulence. It also gives the description of possible scenarios of the Russian luxury market development during the period of economic sanctions.
\end{abstract}

Keywords: luxury, luxury products and services, customer loyalty, typology of loyalty, scenarios of luxury market economic development

\section{Introduction}

Luxury market in Russia had been developing very fast since the end of 1900-Th. Most of the well-known luxury brands are now presenting in Moscow, Saint Petersburg and other big cities of Russia (including the cities on Far East part of Russian Federation-Magadan, Yughno-Sachalinsk, Vladivostok). The distributors of luxury brands such as Mercury, Bosco di Chilegi, Gimeney Trading house and others are very active in Russia. In 2014 the downturn of the sales of automobiles, cloth, accessorise were registered in the sector of middle or low priced products. This situation is affected the market of premium and luxury goods and services as well, because of the changed in consumer behaviour. The economic sanctions of the Western countries to Russia, than the dramatic change of the Russian currency rate in autumn of 2014 created stressful situation for the importers and distributors on the market of luxury goods. The possible scenarios of the economic development of Russian luxury products markets are: "Iran scenario", scenario "As it was in 2008-2009", scenario "Using social and psychological factors of consumer behaviour", scenario "Changing the notion "Luxury" as a whole" are developed and described. The possibility to use the consumer loyalty can also help to maintain the luxury market in Russia during recession.

\section{Literature Review}

Thorstein Veblen and Werner Sombart, the founders of institutional economics and the theory of luxury consumption examined the phenomenon when consumption of luxury brands grew in early 20-s. Their research proved that luxury is a symbol of consumer's status which exclusively belongs to upper class, a so-called leisure class. According to Veblen and Sombart luxury brands serve to enhance a person's status and prestige in society and to exalt him above others. At the same time these authors mentioned that luxury is usually regarded by consumes or other members of the community as "expenditures that exceed required limits" (Veblen, 1984; Sombart, 2008).

Moreover, Simon Kemp's research shows that "goods are perceived as luxury if they are able to evoke positive emotions more than discomfort (for example the sum of money the customer paid for the product)". In other words consumption of luxury products and services is capable to decrease consumers' cognitive dissonance. Kemp compares scale "luxury-necessity" with Maslow's hierarchy of needs which ranges customer's motivation of behaviour from physiological (food, accommodation) to self-expression and self-esteem (status, luxury) 
(Kemp, 1998). In early, 2000-s Michael Silverstein and Neil Fiske introduced a new term "affordable luxury". The term appeared as a result of changes taking place within the luxury market at the end of 90s to early 2000s. Particularly at that period of time such countries as China, India, Russia and Brazil demonstrated the emergence and development of the luxury market. High class premiums were included into the "affordable luxury" category, as affordable to customers. (The authors named this product category "mass prestigious goods" or "masstige") (Silverstein \& Fiske, 2004).

Producers of luxuries scrutinize major customers' needs, which afterwards become the foundation for brand promise. Research of the Russian luxury market conducted by the authors of this article as well as comparative analysis with traditional luxury markets (European, Northern American and partially Japanese) and other developing markets (BRICS countries) revealed that customers expect the following values from the product as well as brand:

1) Unique brand or product character;

2) Exceeding quality level (often reached as a result of introduction innovations);

3) Brand image and brand prestige;

4) Exclusiveness (limited edition);

5) High price meets quality;

6) Highest service standards.

Three main reasons (motivations) to consume luxury goods were distinguished and described by Harvey Leibenstein. They are the following: Bandwagon effect, Snob effect and Veblen effect (Leibenstain, 1950).

Bandwagon effect means that customers are eager to acquire a luxury good or service to match the main modes of behaviour demonstrated by the representatives of the social class this customer would like to emulate.

Snob effect demonstrates the eagerness of customers to show off and helps to improve the perceptible status of such consumer in society.

Veblen effect presupposes motivation to demonstrative (ostentatious) consumption.

The consumer values of buying and consuming luxury and premium brands are different from the consumption of mass products, and it differentiates from country to country. Luxury products have become available to a wider range of consumers in different countries. The European researchers (Hennigs et al., 2012) stated "The traditional conspicuous consumption model has been transformed into a new experiential luxury sensibility that is marked by a change the way that consumers define luxury". The empirical study of them showed that consumers in different geographical regions are showing similar values and trends in luxury consumption. Another motivation for the customers to buy luxury goods is country-of-origin (COO) effect of the brand. It is defined by several research projects, which were done by international group of researchers. (Aiello et al., 2009).

These effects upon consumer perceptions and purchase intentions remain of interest to marketing researchers. Research conducted by the authors of this article as well as by other experts proved that Chinese, Russian as well as some other consumers mainly from developing markets demonstrate Veblen effect, i.e. demonstrative (ostentatious) consumption. For example, well-off Chinese consumers purchase well-recognized luxury brands. Radha Chadha and Paul Husband state "Chinese consumers possess certain specific traits of their character. They do not necessarily have superb accommodation but they must have a good car and expensive watch" (Chadha \& Husband, 2007). These customers also demonstrate a desire to purchase luxury bags or other accessories since such goods are always seen by other members of the community and this can be also regarded as another feature of Chinese customers' purchasing behaviour.

Tony Hines and Margaret Bruce as well distinguish some additional features characterizing modern consumers of luxury brands. They can also be applied to the Russian consumers of luxuries, especially of fashionable designer goods (Hines \& Bruce, 2007):

- High level of personal identity and individuality;

- Customer's participation in luxury product development. In marketing practice this is known as "customization";

- Customers' activity in Internet and social nets. As a result there is a great possibility of their receiving, perceiving and assessing new information in a flash;

- High educational level; 
- High level of customer confidence concerning their current and future social and economic status;

- Even higher status of intangible luxury (emotions, impressions) over material ones;

- Consumers' readiness to purchase luxuries at high price as high price signals high quality and motivates them to consume these products.

Turbulent situation in economy could sometimes make producers and retailors bring prices down in order to stimulate demand, though this situation is more typical of mass market and rarely affects luxury market.

Some economists are sure that contrary to mass market, decrease in price for luxury brands in long-term perspective will result in decrease in demand. In the wake of Dubois, Czellar, Laurent and Duquesne the phenomenon known as premium product price paradox (Dubois, Szellar, \& Laurent, 2005; Dubois \& Duquesne, 1993; Vigneron \& Johnson, 1999).

Yearly price lowering for luxury brands stimulates customers to make expensive purchases at once without putting them off for later periods of time. All these factors are of great importance in critical economic situations as producers of luxury goods will not be affected by acute fluctuations of sales volumes.

\section{Influence of Financial Crisis and Turbulent Economic Conditions on Consumption Models in Russia}

Statistical data demonstrate yearly decrease of wealthy people in Russia. In accordance to Federal Tax Service of Russia (FTS of Russia) cited by Interfax news agency "the number of billionaires reduced by $12 \%$ from 2011 to 2012 and this figure persisted throughout 2012" (Federal Tax Service of Russia, 2012).

This means that competition among companies dealing with luxury is escalating and they find it more and more difficult not only to attract new clients but also to retain the existing ones and to develop and maintain loyalty to their brands.

The book entitled "Chaotica" written by famous marketing guru Ph. Kotler together with his co-author John Caslion describes the condition when a market rapidly loses growth rate and the economy as a whole is under financial recession as turbulence (Kotler \& Caslion, 2009). Economists, marketers, producers and retailors working on luxury market in various countries including Russia, find it extremely interesting to examine the changes taking place within consumer behaviour under the influence of turbulence. They also wonder whether consumer loyalty to luxury brands will be able to sustain under such hectic conditions.

The economic recession has always got a very strong influence on the personal consumption.

Financial crisis in Russia in 2008-2009 substantially changed the current financial position of many Russians - unemployment rates increased, fringe benefits, salaries, power ups were cut, savings reduced. Shift in income led to changes in consumption model, which was named "protective model" by two Russian economists Grigoriev and Salamina (2009). The main idea of this model is to secure earnings by cutting expenditures on predominately durable goods, discrete purchases (culture, entertainment). Families cut expenditures on some FMCG goods, for example, on food products as well as some services. According to various surveys conducted in Russia, the major approach to spending optimization used by average consumers was to switch from more expensive products to less expensive ones, for example package tours.

At the same time the survey conducted by Omnicom Media Group in August 2009 researched the trends of consumer behaviour at the time of world recession in European countries, including Russia as well as in the countries of Asia and Latin America (Omnicon Media Group conducted large scale consumer research in time of recession, 2009). The survey stated that consumers demonstrated shifts in their behaviour, laying more emphasis on rational factors while making purchase decisions. Within the framework of the survey 8 key types of consumer behaviour were determined. Table 1 Gives the authors' description of the type of consumer behaviour and the possible marketing efforts, which can be taken into account by manufacturers and distributors.

Table 1. Typology of consumer behaviour under influence of crisis

\begin{tabular}{lll}
\hline Type of Consumer Behaviour & $\begin{array}{l}\text { Type Description Based on Possible marketing efforts } \\
\text { Omnicom Media Group } \\
\text { Survey }\end{array}$ & \\
\hline $\begin{array}{l}\text { Losing luxuries- } \\
\text { consumers stop or suspend } \\
\text { purchasing luxury products }\end{array}$ & $\begin{array}{l}\text { Consumers decreased Producers and retailors of luxury and } \\
\text { consumption of luxury brands premium-priced goods should analyse the } \\
\text { or ceased their purchases }\end{array}$ & $\begin{array}{l}\text { market and make attempts to stimulate } \\
\text { demand (short-term price decrease, sales }\end{array}$ \\
\hline
\end{tabular}


completely.

Alternative economies - type of behaviour based on mutual product usage as well as on second-hand product purchases.

\section{Smart shoppers-}

consumers actively optimize their expenditures.

\author{
Cocooning \\ consumers - consumers who \\ cut spendings on \\ entertainment and holidays \\ during the recession period.
}

\section{Make do and mend-}

consumers take to so-called "home production".

\section{Free fun-}

these consumers spend most of their time in Internet, mainly economize on digital entertainment devices.

The selfish green-

this type of consumers cherishes the "purity" of the environment as the main spiritual principle of life.

Anxieties and antidotesconsumers change their values under unfavourable economic conditions
This type is characterized by active communication in social nets. Consumers are apt to socialize a lot and belong to the communities where members usually give a helping hand by selling and buying various products they need from each other.

Price is the main driving force for this customer type.

They spend a lot of time making comparisons of price offers and finally select the best price. Such consumers are also greatly influenced by special offers, discounts and sales.

This group of consumers tends to spend more time at home. But if they have to go out, they will prefer to select a restaurant, a café or a night club with special price offers.

Consumers become involved in making their own clothes, growing fruit and vegetables in their personal gardens, saving money on certain product categories.

Their main source of economy is predominately digital entertainment devices.

Even during recession period they continue purchasing highly-technological and environmentally friendly products, though the products of this category are much more expensive.

Consumers abruptly change their life values, shifting their priorities from material welfare to spiritual values, such as family, religion, health care, communication. promotion campaigns) in order to retain customers.

To develop special marketing on-line programs, i.e. to develop and manage customer group interaction within social nets.

To develop special advertising messages, describing both current pricing policy and all sales promotion activities.

To develop entertainment chains with special flexible pricing policy (for example price changes depending on time of the day, day of the week )

To develop the market "do it yourself"-goods for sewing, gardening (i.e. seeds), home equipment for home and garden.

To develop on-line marketing for producers so that they can inform their customers about product availability, prices, special offers and sales.

To develop offers of highly-technological and environmentally friendly products, special communication programs.

To offer special programs and products oriented on such customers. 
Thus, influenced by turbulent economic conditions, consumers evolve, change habits and consumption culture mostly affected by rational motives in his/her buying decisions. Market participants in this case should regard such conditions as not only arousing problems but also as granting opportunities for changing their marketing strategy and methods of communicating with customers. Despite changes in consumer behaviour in favour of rational motives, consumers, nevertheless, do not reduce their needs in purchasing high quality products and services. The survey conducted by Omnicom Media Group in 2009 showed that $42 \%$ of European consumers were ready to pay extra money for higher product quality. Meanwhile some consumers were ready to change some of their brand preferences and to switch to more rational brand offerings. $47 \%$ of respondents in Russia agreed to that statement.

Research conducted at marketing department of Plekhanov Russian University of Economics demonstrated that loyalty could be maintained and even increased within premium customer segment under recession if familiar brand image is preserved. Survey made by Irina Skorobogatykh and Volkova also proved this postulate (Skorobogatykh \& Volkova, 2009). Research conducted in 2009 showed that in spite of pessimistic forecasts concerning declining demand for highly-priced goods, a company producing detergents for premium segment managed to sustain a leading position for quite a long period and even increased consumer loyalty. Customers who have a habit of consuming high quality goods happened not to switch to cheaper goods but stayed committed to old, proved brands even during recession. Consequently, according to forecasts companies with stable client base in which loyal customers prevail are likely to be successful in spite of forthcoming period of economic uncertainty, steep decline of national currency exchange rate which started in November 2014.

\section{Interrelation between Customer Loyalty and Recession}

According to the analysis conducted by Bain \& Co Consultancy, due to economic recession and uncertainty, the Russian market of luxury and premium segment consumer goods is supposed to decrease approximately by $18 \%$ (up to 4.6 billion Euro). In contrast to this statistics, recession of 2009 resulted in only 5\% market fall. Initially Bain \& Co mentioned only a $4-6 \%$ of decline in demand. Later on, however, they reconsidered their position owing to rouble devaluation and overall loss of consumer confidence (Bain \& Co, 2009). Unfavourable tendencies could be traced by the example of premium clothing sector. Buyers and sellers then used credit resources for procurement of their collections. Increase of Russian Central Bank exchange rates will result in decrease in procurement in the first half of 2015 by approximately 30\%. According to experts' estimates drop in luxury brands sales was recorded even in some Western European countries. The experts from Bain \& Company report that trips abroad were not recommended or even legally banned to officials of Russian state corporations. Russians in line with other BRICS citizens are known to be active byers of luxury goods in Western European countries.

Researchers of Russian luxury product market should ask at least two questions:

i. What will be the tendencies of luxury product consumption in 2015 ?

ii. How can economic sanctions imposed against Russia affect byres' behaviour of luxury brands and their loyalty? In particular, introduction of sanctions resulted in sharp decline of economic growth and national currency exchange rate in comparison to US dollar and euro.

In the authors' opinion concept aimed at increasing customer loyalty could relieve increasing pressure of turbulence laid on luxury market. In our previous works we (Shirochenskaya, 2009; Shirochenskaya \& Tarasenko, 2013) discussed the issue of multilevel nature of loyalty in detail.

Based on all of these the possible scenarios of luxury market development can be formulated.

\section{Results}

The outcomes of the conducted research and statistical data presented above, give us the right to formulate certain scenarios that forecast luxury market development.

Since there is no production of luxury brands in Russia, the market exists only by means of export.

Scenario 1. Both economic and political situations have worsened. In the light of this luxury market could be developed in accordance with so-called "Iran scenario". This scenario presupposes complete import embargo of luxury finished goods. Thus, Iran authorities banned import of any luxury products. This was caused by necessity to decrease currency spending under sanctions imposed against Iran and local currency devaluation. The value of national currency real dramatically fell by the beginning of October 2012 (Nigmatullin, 2014). A list including 75 luxury and premium brands including cars, laptops, watches, mobile phones was made. Besides that coffee and some hygienic products were also attributed as luxury goods. Though these measures were 
directed at only finished goods, spare parts for watches, laptops and mobile phones were not regarded as luxury goods and consequently were not banned. They are used to assemble finished goods on the territory of Iran. European Union has also refused to buy oil from Iran from June 1, 2012. USA as well imposed economic sanctions against this country. Due to all these factors Iran had to cut exchange expenses.

This example gives us the right to assume that Russian producers of luxury souvenirs will have to develop their production at full scale under similar conditions. These products are mainly crafts representing various Russian regions. They can as well enhance tourist attractiveness of these regions that is great demand. Among the products we can name exclusive lace from Eletsk and Vyatka Regions, wooden painted panniers from Northern Russia-Arkhangelsk, traditional Russian products made from elm, enamel from Rostov the Great, wooden painted and lacquered boxes from Palekh region, Zhostov trays, hand-made toys from Tula, Dymkovo and Filimonovo and some others. These products stress the national features and are directly linked to the country of origin. They all have got a huge potential for being developed into real brands, purchased like real luxury brands with emphasis on emotional motivation. Customer loyalty in this case should be based on principle of psychology. It can be strengthened and maintained by means of improving quality of national brands. In this case trust of Russian consumers as well as international tourists could be gained.

Scenario 2. If the market manages to avoid "Iran scenario", the crisis of 2015 could directly reflect consumer behaviour during the economic crisis of 2008-2009, the features of which were fully described in this article. One can assume that genuine luxury, really expensive and exclusive goods would be of demand to a rather tiny consumer segment, i.e. wealthy people whose financial position is not very much affected by any kind of economic crisis or recession. Nevertheless, these products will turn to be less and less affordable for mass market. The situation will be caused by growing price for these goods owing to exchange rates of rouble and world currencies (US dollar and euro) and expensive export.

The authors can follow the opinion expressed by Vyacheslav Bobkov, General Director, Russian National Centre for Standards of Life, head of Department of Labour Economics and HR management at Plekhanov Russian University of Economics (PRUE) who said: "upper middle class (the major consumer of affordable luxury and middle class will gradually descend to a more low-income position during recession, while low-income class will get through a short-term period of economic improvement in 2010-2013 and will return to the initial financial position" (Yakoreva, 2014; Omnicon Media Group, 2009). Analysts from "Expert" magazine therefore claim that consumers in 2014 did not economize on cars despite the economic uncertainty and turbulence. Premium brand development strategy assists in increasing demand for premium-priced luxury brands. It is directed at offering customers more affordable versions of favourite premium brand cars. 2014 generally demonstrated sales growth in premium brand car sector. Table 2 proves these conclusions in general, except noted boom for cars in December 2014. This situation was caused by fluctuation with the exchange rates and the decline of Russian national currency as well as customers' pessimistic expectations of forthcoming unfavourable conditions (Denisenko, 2015).

In accordance with the data from gazeta.ru - the biggest Russian internet media edition, Russian car dealers and car shows experienced deficit for premium cars in December 2014. In November-December 2014 sales doubled. Nevertheless all experts and car market analysts express general concern for the forthcoming difficulties for this market throughout 2015 (Russians have bought out premium-priced crossovers and SUV vehicles, 2015).

Table 2. Sales volume of premium car brands, November, 2014 in comparison to November, 2013

\begin{tabular}{lllll}
\hline$\#$ & Brand & $\begin{array}{l}\text { Sales volume in } \\
\text { November } \\
\text { (units) }\end{array}$ & $\begin{array}{l}\text { Sales volume in } \\
\text { November } \\
\text { (units) }\end{array}$ & Growth/fall (\%) \\
\hline 1. & BMW & 34888 & 31927 & $-8,4$ \\
2. & Audi & 33565 & 31031 & -7.5 \\
& & & & \\
3. & Mersedes-Benz & 40211 & 44955 & +11.8 \\
4. & Land Rover & 18809 & 19078 & $+1,4$ \\
5. & Porsche & 3382 & 4030 & +19.1 \\
6. & Lexus & 14294 & 17661 & $+23,5$ \\
\hline
\end{tabular}


The second scenario presupposes that customer loyalty to luxury brands will perform key role for producers. It will be extremely difficult to attract new customers due to lowered income levels. Besides that loyalty programs aimed at luxury brands and services will need thorough revision. Loyalty can be strengthened by giving new additional premium-quality services, exclusive after-sales and service programs. On purchasing a luxury brand, customers value premium level of service most of all. Thus, trust and commitment are the most fragile elements restored with great difficulty. In order to retain a new customer who has made no more than two purchases yet (for example, stayed at a luxury hotel more than 2 times), it is immensely important to strengthen the role of loyalty programs aimed at luxury services. Such customers often demonstrate pseudo (false) loyalty to a hotel brand and are ready to shift to an alternative brand if the competitor's offer turns out to be more attractive (Tarasenko, 2011).

Scenario 3. Let's assume that the crisis affects social and psychological factors that influence customer behaviour of luxury brands and services.

In this case demonstrative (ostentatious) consumption of luxury will be limited or completely disappear. Personal factor known as social status will affect consumption as well as the "income anticipation effect". Influenced by the latter, many consumers of affordable luxury will make luxury purchases. Loyalty will also undergo changes as it will be mainly directed at brands proclaiming and promising social responsibility of business.

The role of corporate image, goodwill and charity will arise respectively. A good example is a charity festival called "Dushevny Bazar". Several VIP-tourist companies and fashion houses working in luxury industry took part in it in December 2014. The money gained from the event was sent to more than 800 charity companies throughout Russia. "Alternative economies" consumer behaviour model discussed above can be applied in this context. In particular, one can see intensifying exchange of luxury brands via specialized internet resources, social nets, internet shops. Thus, articles of luxury second-hand clothes in good condition, jewellery, bags, and shoes and so on can be bought and sold by means of internet or social nets.

Scenario 4. Change of notion "luxury" as a whole. The definition of luxury in time of recession is never so close to criteria provided by Hans Magnus Enzensberg and is likely be used in Russian environment of luxury by the end of 2015 г. According to Enzensberg, luxury is oriented to such values as time, attention, amplitude, tranquillity and reliability (features are given in order of increasing value). These values are of little dependence on social status, moreover, nowadays many wealthy people, elite - paradoxically, are unable to allow themselves much from this list. So these values are prerogatives of jobless, elderly and tramps, who, as a rule have a lot of spare time and personal freedom in their possession though, without regarding this as a benefit (Calefato, 2004).

\section{Discussions}

The changes in economic condition of both market and society in Russia, under which producers, distributors and dealers have to adjust to turbulence at time of recession as well as economic sanctions imposed against the country by the Western world will not fail to affect premium-class and luxury market. Price increase for luxury brands and services as well as premium-class goods is expected to come. Shifts in consumer behaviour are also of expectance. In spite of the interest, knowledge of band, its background, previous buying and usage experiences, it is expected that middle-class consumers will be guided by rational consumer motivation. In contrast to them, more well-off customers are likely to reduce the level of consumption but not too intensely.

Loyalty development, service quality improvement and well-planned and well-established marketing efforts aimed at buyers' behaviour analysis, development of company's assortment and building special marketing programs to stir up interest and stimulate demand as well as customers' trust in luxury market can be regarded as the way of solving problems of market stagnation and slowing down market development.

Depending on the scenario that is more likely to be realized in the Russian market of luxury goods \& services by the end of 2015 it seems reasonable to conduct the supportive ongoing marketing survey in order to prove or disprove the hypothesis: 1) Scenario 2. There is a measurable difference in the way the customer consumption of luxury and customer's loyalty is formed in Russia towards the luxury brands as compared to Europe during the economic turbulence (the research can be conducted in Russia and Norway \& France among the selected focus groups of consumers. Norway is chosen as the most distant country judging from the cross-cultural perspective, France is more similar due to the higher proportion of power distance in the society and, hence, more tendency to buy status goods \& services). 2) Scenario 1. The consumption of craft works and luxury souvenirs, and art objects produced in Russia will significantly be increased by the end of 2015 as well as the product lines will be modified to match the changing patterns of customer demand ( the research can be executed by performing the statistical analysis of the 2-3 selected, independent producers in different cities of Russia). 3) Scenario 3 During the economic turbulence The social and psychological factors that influence and change the consumer behavior 
and attitude towards luxury and cusomer's loyalty can be named as well their relative share (weight) can be assigned to each of them (this can be done by conducting a series of interviews, online as well as offline, in focus groups.; the further results of thev reserach will be mathematically proven by means of impact analysis. 4 . The forth forecasted scenario however lies beyond the scope of the means of the mere marketing research and, if developed at all, will most likely be traced for in the next few decades to come.

\section{Acknowledgements}

The authors express the gratitude to the management of the Plekhanov university of economics: vice rector of the research professor Elena Zarova and the Head of the department of the organisation and management of research projects professor Ksenia Ekimova for the support and continuous help in all research projects conducted at the marketing department. In addition, we would like to give our impressions to the Dean of marketing school professor Asali Asaliev, who gives authors opportunity to present results of the research during Plekhanov RUE's marketing school week of science.

\section{References}

Aiello, G. et al. (2009). An international perspective on luxury brand and country-of-origin effect. Journal of Brand Management, 16(5-6), 323-337. http://dx.doi.org/10.1057/bm.2008.52

Calefato, P. (2004). The Clothed Body: Dress, body, culture (p. 224). Berg Publishers. http://dx.doi.org/10.2752/9780857854049

Chadha, R., \& Husband, P. (2007). The Cult of Luxury Brands. In Inside Asia's Love Affair with Luxury. London: Nicholas Brealey Publishing.

D'Arpizio, C., Levato, F., Zito, D., \& de Montgolfier, J. (2014). Research of the development of markets of luxury of the company BAIN\&Co research company. Retrieved from http://www.bain.com

Denisenko, O. (2015). Overcoming Economic Turbulence in Premium Segment of Car Market by Means of Marketing Technologies. All-Russian Scientific and socio-educational journal Initiatives of 21-st century, 1 .

Dubois, B., \& Duquesne, P. (1993). The Market for Luxury brands: Income versus Culture. European Journal of Marketing, 27(1), 35-44. http://dx.doi.org/10.1108/03090569310024530

Dubois, B., Czellar, S., \& Laurent, G. (2005). Consumer Segments Based on Attitudes Toward Luxury: Empirical Evidence from Twenties Countries. Marketing Letters, 16(2), 115-128. http://dx.doi.org/10.1007/s11002-005-2172-0

Federal Tax Service of Russia (FTS of Russia). (2013). Retrieved from http://www.nalog.ru/rn77

Grammatchikov, A., Inkizhinova, S., Litvinova, N., \& Chebotarev, A. (2014). Customer in Sleep Mode. Expert magazine, 26(905).

Grigoriev, L., \& Salmina, A. (2009). Forced Self-Defense. In Changing Buying Behaviour: Model in Tmies of Economic Crisis. Retrieved from http://www.vremya.ru/print/236885.html

Hennigs, N. et al. (2012). What is the Value of Luxury? A Cross-Cultural Consumer Perspective. Psychology and Marketing, 29(12), 1018-1034. http://dx.doi.org/10.1002/mar.20583

Hines, T., \& Bruce, M. (2007). Fashion Marketing. Contemporary Issues (2nd ed., p. 111). Oxford, UK.

Kemp, S. (1998). Perceiving Luxury and Necessity. Journal of Economic Psychology, 19(5), 591-606. http://dx.doi.org/10.1016/S0167-4870(98)00026-9

Kotler, P., \& Caslion, J. (2009). Chaotics: The Business of Managing and Marketing in the Age of Turbulence (p. 224). NY: AMACOM Publishing.

Leibenstein, H. (1950). Bandwagon, Snob and Veblen Effects in the Theory of Consumers' Demand. The Quarterly Journal of Economics, 64(2), 183-207. http://dx.doi.org/10.2307/1882692

Nigmatullin, T. (2004). Sanctional Wars: Try on Iranian Scenario for Russia. In Independent Analytical Agency Inverscafe. Retrieved from http://investcafe.ru/blogs/64668638/posts/44117

Raspopova, A., \& Lomakin, D. (2014). Russians have bought out all premium-priced crossovers and SUV vehicles. Retrieved from http://static.gazeta.ru/auto/news/2014/12/16/n_6749397

Shirochenskaya, I. (2009). Methods to Determine Typology of Loyalty. Contemporary Aspects of Economy, 11, 341-366.

Shirochenskaya, I., \& Tarasenko, E. (2013). New Tendencies in Loyalty Programs Development and Customer 
Relations Management. All-Russian Scientific and socio-educational journal Initiatives of 21-st century, 4, 64-70.

Silverstein, M., \& Fiske, N. (2008). Trading Up: The New American Luxury. In Portfolio Trade (p. 320).

Skorobogatykh, I., \& Volkova, M. (2009). Marketing under Crisis: New Opportunities and Strategies. All-Russian Scientific and socio-educational journal Initiatives of 21-st century, 2, 41-45.

Sombart, W. (2008). Luxury and Capitalism. War and Capitalism. Complete Works (Vol. 3). St. Petersburg: Vladimir Dal.

Tarasenko, E. (2011). Economic Crisis is the Time to Promote Services of High-class hotels Russian Enterprise, 1(177), 134-139.

Veblen, T. (1984). Theory of Leisure Class: An Economic Study of Institutions Progress Publishing. Moscow.

Vigneron, F., \& Johnson, L. W. A. (1999). Review and a Conceptual Framework of Prestige-seeking Consumer Behaviour. Academy of Marketing Science Review, 1.

Yakoreva, A. (2014). Not in Favour of New Poor. Kommersant. Retrieved from $\mathrm{http}: / / w w w . k o m m e r s a n t . r u / d o c / 2624233 ? 9 f 476940$, the date of inquiry 14.01.2015

Zuban, O. (2009). Omnicom Media Group (OMG) conducted large-scale consumer research in time of recession. Retrieved from http://adindex.ru/news/researches/2009/11/6/31273.html

\section{Note}

Note 1. The name of the festival can be translated as "Heartwarming Fair".

\section{Copyrights}

Copyright for this article is retained by the author(s), with first publication rights granted to the journal.

This is an open-access article distributed under the terms and conditions of the Creative Commons Attribution license (http://creativecommons.org/licenses/by/3.0/). 